\title{
Building Critical Thinking Skills Through a New Design Mobile-Based Interactive Learning Media Knowledge Framework
}

\author{
https://doi.org/10.3991/ijim.v15i17.23801 \\ Patni Ninghardjanti ${ }^{(凶)}$, Chairul Huda Atma Dirgatama \\ Universitas Sebelas Maret, Jawa Tengah, Indonesia \\ buning@fkip.uns.ac.id
}

\begin{abstract}
Several initiatives have been made to overcome educational problems, ranging from improving the curriculum, developing and improving the quality of teachers, developing student abilities, and other efforts related to improving the quality of education. This study analyzed critical thinking skills built based on perceptions of mobile media, self-directed learning, and digital literacy. The research method used was a quantitative approach utilizing a questionnaire as the instrument. The questionnaire was distributed to students who enrolled in record management using previously produced interactive mobile media. The sampling technique used was probability sampling with the type of random sampling. Data analysis included analyses of prerequisite tests, including validity and reliability tests. The data were then analyzed using a structural equation model (SEM) analysis using the SPSS Amos application version 26. The results showed that 1 ) the variable of the perceptions on mobile media could not affect critical thinking skills directly, 2) there was a significant positive effect on the variable of perceptions on online learning media on self-directed learning, 3 ) there was a significant positive effect on the variable of perceptions on online learning media on digital literacy, 4) there was a significant positive effect on the variable of self-directed learning on critical thinking skills, 5) there was a significant positive effect on the variable of digital literacy on critical thinking skills, 6) the variable of perceptions on mobile-based learning media had a significant positive effect on critical thinking skills through self-directed learning mediation, 7) the variable of perceptions on mobile-based learning media had a significant positive effect on critical thinking skills through digital literacy mediation.
\end{abstract}

Keywords-learning media, mobile learning, critical thinking, vocational school, education

\section{Introduction}

Education is an essential aspect of a country's development, which functions as a mechanism of the system to educate the nation's generation. It becomes a benchmark in assessing the progress of a country, which is also applied to Indonesia. Although education development is a particular concern in government policy, the reality in 
Indonesia leads to complex conditions. One of the organizations that assess or evaluate students' academic abilities in various countries is The Organization for Economic Co-operation and Development (OECD). The OECD uses the test system called Program for International Student Assessment (PISA), which is carried out in three primary academic areas: reading, mathematics, and science.

Based on the issues discussed above, essential conclusions can be drawn in the background of these research problems. Education is a crucial component in developing the quality of human resources in a country, including in Indonesia. As a developing country, Indonesia is still experiencing some human resource problems when viewed in education based on the PISA test results. Based on the latest report of PISA involving 78 countries, the reading and mathematics score of Indonesian students was ranked 72 , while the science score was ranked 70 [38]. These results suggested that there is a problem with the quality of education, which has a direct effect on scholarly output in the form of human resources. The scholarly output based on the curriculum implemented in Indonesia requires students to have particular knowledge and competencies, such as critical and deep-thinking skills. However, based on the initial observations conducted by this study, the critical thinking skills of the samples of students were low, with only a few of them possessing high critical thinking skills. Several factors related to and affect the ability to think critically include learning media, self-directed learning, and digital literacy. The relationship of these three factors with critical thinking skills forms a new design in the framework of mobile-based media knowledge. Therefore, this study seeks to confirm the relationship between these variables and determine the form of the relationship and the significance of the new design in mobile-based media knowledge.

This description shows that education is expected to prepare human resources capable of facing the changes and challenges of the times. Quality human resources in Indonesia can only be generated by improving the quality of education. This improvement can be carried out by adjusting the teacher-centered learning system implemented towards more meaningful student-centered learning [1]. The learning system that directs its focus on students will foster and develop creativity and train students' critical thinking skills in learning and solving problems faced in daily living [30]. However, the weakness in this learning system is the lack of attempts to develop students' thinking skills $[11,19,48]$. This weakness eventually distorts, if not wholly hinders the completion of the final goal of learning, which is mastering thinking skills. Indeed, teachers teach students to learn but do not teach them the proper way of thinking to learn [62].

All learning differs from one subject to another, including record management in the Office Administration Department. On the ground that every subject requires accuracy and skill in thinking [59], a preliminary observation was conducted to determine the state of students' critical thinking skills in the subject of record management. The following table presents the results of preliminary observations regarding critical thinking skills in several schools in Surakarta: 
Table 1. The results of the critical thinking skills of 10th-grade students in the subject of record management in vocational high schools in surakarta

\begin{tabular}{|l|c|l|c|c|}
\hline \multicolumn{1}{|c|}{ No } & Score & \multicolumn{1}{c|}{ Criteria } & Frequency & Percentage \\
\hline 1 & $76-100$ & Very Good (VG) & 2 & $10 \%$ \\
\hline 2 & $51-75$ & Good (G) & 5 & $25 \%$ \\
\hline 3 & $26-50$ & Moderate (M) & 5 & $25 \%$ \\
\hline 4 & $0-25$ & Poor (P) & 8 & $40 \%$ \\
\hline
\end{tabular}

Source: Primary data processed, 2020.

A total of 20 students of 10th-grade students in record management were sampled for preliminary observation. Table 1, which presents the critical thinking skills test results, shows that students' skills can be categorized evenly in the moderate and very good categories. Out of 20 students, two students or $10 \%$ were in very good criteria; 5 students or $25 \%$ were in the good criteria; 5 students or $25 \%$ were in the moderate criteria, and eight students or $40 \%$ were in the poor criteria. These results indicate that most students who enroll in record management have not formed critical thinking skills.

It shows that the standard process encounters issues. Many aspects of indicators can be used to measure the success of the learning process, including support from learning media [7]. The use of media, including mobile learning applications, is proven to be able to provide a positive stimulus in learning $[21,36]$. Several studies have conducted the development of mobile learning applications. As a result, various abilities can be improved through the use of mobile media, including learning ability [42], analytical ability [41], creativity ability [40], and critical thinking [42]. Furthermore, the advantage of using media is to evaluate learning implementation [40, 43]. Besides learning media, other ways can help develop critical thinking skills, such as self-directed learning $[2,60]$. In addition, through self-directed learning, students can improve their problem-solving skills [24]. Self-directed learning can also be improved and affected by several factors, including perceptions and literacy skills in digital media $[38,50]$.

Based on the above overview, this study would confirm quantitatively that critical thinking skills can be improved through digital and mobile media perceptions, self-directed learning, and digital literacy. Furthermore, this study would reveal the relationship between the variables of critical thinking skills, including self-directed learning, digital literacy, and the perceptions of mobile-based learning media. Based on the background that has been described above, the problems that can be formulated are (1) do the perceptions of mobile-based learning media have a significant positive effect on self-directed learning? (2) do the perceptions of mobile-based learning media have a significant positive effect on digital literacy? (3) do the perceptions of mobile-based learning media have a significant positive effect on critical thinking skills (4) does self-directed learning have a significant positive effect on students' critical thinking skills? (5) does digital literacy have a significant positive effect on students' thinking skills? (6) Do mobile-based learning media perceptions significantly positively affect critical thinking skills through self-directed learning? Furthermore, (7) do the perceptions of mobile-based learning media have a significant positive effect on critical thinking skills through digital literacy skills? 


\section{$2 \quad$ Literature review}

This section discusses each variable, which is seen empirically by understanding it based on the metadata created and the indicators that make up the variable. The relationship between these variables forms a path relationship that needs to be proven by empirical research in the field. It illustrates that the main objective of this study is to prove the relationship formed in the theoretical study empirically.

\subsection{Students' critical thinking skills}

Definition of critical thinking skills. Humans need skills to create a quality workforce [35]. Critical thinking is the skills to identify, analyze, and evaluate situations, ideas, and information to formulate responses to problems so that it always uses logic and reasoning to identify the strengths and weaknesses of alternative solutions, conclusions, or problem approaches [28]. It is also the skills used to make judgments and choices based on information obtained to express an idea [15]. These skills involve questioning sources of knowledge, testing the validity of the obtained information, analyzing its reliability, and drawing appropriate explanations for a specific task or situation $[16,31,50]$. According to Goodsett (2020), the primary components of critical thinking skills include clarification, assessment, justification, connecting ideas, and novelty. Clarification is accomplished by asking and answering clarifying questions about a given topic utilizing information and communication technology (ICT).

Indicators of critical thinking skills. The process to improve critical thinking skills is established from the presence of a problem. According to Facione, six primary critical thinking skills are involved in the critical thinking process, including interpretation, analysis, evaluation, inference, explanation, and self-regulation [6]. Critical thinking is also the skill of using ICT to make judgments and choices based on information about the resources obtained and communicating reflectively with sufficient evidence to express ideas [58]. Critical thinking is broadly used in education, psychology, and philosophy, and repeated attempts have been made to define the concept to increase understanding of how this cognitive ability can be used [56]. More recently, it has been defined as a purposeful, self-regulatory assessment, which results in interpretation, analysis, inference, and explanation of the evidence, concept, methodology, logical or contextual considerations that become the basis of the assessment [22]. These components are involved in the definition of critical thinking skills according to [11], including making arguments, interpreting, thinking appropriately about thinking, and using critical thinking as new knowledge. The study's findings [59] simplified these core components by adjusting respondents of students and professionals into three primary indicators, including reflection, justification, and novelty.

\subsection{Students' perceptions of mobile-based learning media}

Formation of students' perceptions of mobile media. Multimedia is one of the learning media that combines several elements of media presented in computer media. Media is a Latin word, originated from the word 'medium,' which means an 
intermediary or something used to convey, deliver, or carry something [39]. Based on the meaning of the words 'multi' and 'media,' we can interpret multimedia as a combination of various media such as text, animation, pictures, videos, and others, that are put together in the form of digital files assisted by computers, which help convey information or messages [36]. Furthermore, multimedia that the user can control is called non-linear multimedia or often known as interactive multimedia. Interactive multimedia is a solution to facilitate students to learn materials conveniently compared to monotonous textbooks/e-books. An example of interactive multimedia is a learning presentation that allows the users to choose which topic they want to study without waiting for the complete presentation to be broadcast [60]. The interactive multimedia using the basics of animation is developed based on the demands in the field [34, 60]. The materials of the subject will be difficult to understand if they are not accompanied by visualization, which eventually affects the low learning outcomes of students [30]. Furthermore, besides providing visualization, the objective of developing mobile learning is to learn anywhere and anytime [54]. Learning using m-learning provides freedom to users to access learning content anywhere and anytime, without having to visit a particular place at a particular time by using mobile learning.

Indicators of students' perceptions of mobile media. Perceptions are the process of knowing or recognizing objective objects and events using one's senses or, in other words, the process of entering messages or information into the human brain [19]. In this study, the researchers used some instruments in assessing students' perceptions of the media. The measurement was divided into four parts of a central theme, including kinesthetic or ease of media operation, the experience of using media, learning motivation, and authenticity [15].

\subsection{Self-directed learning}

Definition of self-directed learning. Self-directed learning is an attempt made by students to improve knowledge, skills, and achievements related to self-development orientation where they use many methods in various situations and relatively independent time [35]. Self-directed learning is necessary because it can allow students to work on assignments, combining skill and character development, and prepare students to learn their whole lives.

Scope of self-directed learning. Self-directed learning includes the way students learn every day, adapt to rapidly changing circumstances, and take initiatives when an opportunity does not occur or does not present. It is one of the critical determinants of modern pedagogical theory based on active student inquiry, where they control themselves, make choices about learning, solve problems independently, and form abstract conclusions. The success of self-directed learning needs special skills like setting learning objectives, plans to study further, strategies, and evaluation of these learning objectives [56]. Therefore, self-directed learning needs a relatively high cognitive ability. The central issue in implementing self-directed learning is that it requires proactive students to choose learning strategies flexibly and the presence of activities to monitor and control their learning progress [16].

Indicators of self-directed learning. Currently, three tools and theories are used to measure self-directed learning (SDL) in the literature, including the Self-directed 
Learning Readiness Scale (SDLRS), the Oddi Continuing Learning Inventory (OCLI), and the Self-Rating Scale of Self-Directed Learning (SRSSDL). The study used several indicators to measure students' self-directed learning, including the level of awareness, attitudes, motivation, learning strategies, learning methods, learning activities, interpersonal skills, and constructing knowledge [27].

\subsection{Digital literacy}

Definition of digital literacy. The skills to utilize digital information are critical to success in most disciplines and occupations [60]. Digital literacy is critically described as the ability to locate the relationship between digital practice and power and have the capacity to understand the sociocultural context [44]. It can access and share various information sources practically from various media and the ability to present and communicate using processes and devices [8]. It also includes the awareness, attitude, and ability of individuals to utilize digital tools and facilities properly to identify, access, manage, integrate, evaluate, analyze, and synthesize digital resources, build new knowledge, create media expressions, and communicate with others, in the context of a particular situation in life, to allow constructive social action; and to reflect on this process [38].

Digital literacy must be positioned as a right for students to support their full participation in the community because it increasingly mediates social, cultural, political, and financial aspects in life [56]. It can access, comprehend, and create knowledge using devices, platforms, and tools generally called digital or information communication technology (ICT) [54]. A comprehensive definition of digital literacy is the knowledge, attitudes, and skills required to identify, find, access, retrieve, store, and organize information [8]. The focus here is essentially to solve problems, build new knowledge through technology and media in a critical, creative, flexible, and ethical way. Digital literacy is the skills to utilize digital technology, communication tools, or networks to find, evaluate, use, and generate information [31].

Indicators of digital literacy. Many theories about digital literacy are developed by various researchers, such as [23], who researched the measurement of digital literacy of online learning participants during the pandemic. In this study, Bawden's theory of digital literacy formation connects digital literacy with computer literacy and information literacy. The Bawden conception comprises basic literacy skills, background knowledge of information, skills in ICT, and attitudes and perspectives of the users of information [52]. Basic literacy skills involve the ability to read, write, understand symbols, and compute numbers. In the context of online learning, this ability can be in the form of understanding terms and symbols (icons) used in software, creating a file containing text and images, and sharing these files via digital platforms $[32,59]$. Background of information knowledge is the ability to use existing knowledge to explore new information to enrich the existing knowledge. In the context of online learning, background information can be interpreted as the ability to discover information online through search engines and select search results to match the online 
learning context that is being participated. Skills in the field of ICT are creating/ compiling digital content. These skills are the critical competencies in digital literacy, which involve assembling information or knowledge. In the context of online learning, this ability is related to compiling a document or scientific article as a learning output of the subject that is being enrolled. The attitudes and perspectives of information users are behaviors associated with using digital information and communicating content containing information from other sources [8].

\section{Research method}

This study was conducted at twelve vocational high schools in Surakarta City, which have a major in office administration. The study was conducted starting in October 2020 to December 2020. The method used in this study was quantitative research with a descriptive research type. This study used the descriptive quantitative method to solve existing problems based on data in numbers and then analyzed and interpreted. The variables in this study consisted of the perceptions of mobile-based interactive learning media, self-directed learning, and digital literacy as the $\mathrm{X}$ variables (independent) and the critical thinking skills as the Y (dependent) variable.

The research population was all 10th-grade students in the Office Administration Department who had already received record management in mobile-based interactive learning media. The population was 1,960, with a sample of 190 students. This sample was taken from the independent variable indicators and the dependent variable indicator multiplied by 10 . The sample size was 190 since this study involved 19 indicators that included both dependent and independent variables. It was based on the argument of [4] that in a multivariate study, the sample size must be several times (5-10 times) the number of variables to be studied. The sampling technique used in this study was probability sampling with the random sampling type. Random sampling is a sampling technique in which the population is taken randomly using a balanced proportion according to the position in the population. This sampling technique is used based on a homogeneous population that has a definite number.

The data collection technique employed a closed questionnaire with a Likert scale of 1-7 consisting of 57 initial statement items. The statement items consist of 9 statements of critical thinking skills, 12 statements of perceptions of mobile media, 24 statements of self-directed learning, and 12 statements of digital literacy. The validity technique used the Pearson formula (product-moment) with the $r$ count $>r$ table criteria, while the reliability used Cronbach's alpha formula with the criteria $\geq 0.60$. The assumption test used Kolmogorov Smirnov's normality test with criteria of more than 0.05 at a tolerance of 5\%. Hypothesis testing used the Structural Equation Model (SEM) analysis to determine the effect of the variables of perceptions on mobile media, self-regulated learning, and digital literacy on the formation of critical thinking skills through the SPSS Amos application version 26. 


\section{$4 \quad$ Results}

\subsection{Instrument validity test}

Testing the validity of the statement items in the questionnaire aimed to verify the accuracy of these items in measuring the concepts intended in this study. This study used construction validity using the Pearson formula (product-moment) with rough numbers. Questionnaire items can be declared valid if Rcount $>$ Rtable. The value of Rtable is at the $5 \%$ significance level, with the number of $\mathrm{N}$ (amount of data) of 30 respondents was 0.36 . The analysis results show that the validity of each statement item was greater than 0.36 . Therefore, Rcount on each statement item $>$ Rtable (0.36). These results indicate that all 57 statement items were declared valid and could be used in questionnaires distributed to the respondents.

\subsection{Instrument reliability test}

The reliability test in this study aimed to determine the accuracy of the instrument's measurement so that it remains consistent when two or more measurements were made of the same symptoms using the same measurement tool. The instrument reliability test in this study used Cronbach's alpha formula. For each item in the variables, the instrument used would be considered reliable when the Cronbach's alpha $>0.60$. The reliability test in this study used the SPSS Amos application version 26. These results show that the values of all statement items had a Cronbach's alpha value $>0.60$. Therefore, all 57 statement items were reliable and feasible to be distributed among respondents.

\subsection{The results of hypothesis testing}

Structural model evaluation. Structural models can be evaluated using r-squares for each endogenous latent variable as predominant strength and structural models. In this study, hypothesis testing was performed using the magnitude of the structural coefficient and stability of the estimate, which was evaluated using the $t$-statistical test. The test was obtained through a bootstrapping procedure.

Table 2. The r-squares values

\begin{tabular}{|l|c|}
\hline \multicolumn{1}{|c|}{ Variable } & r-Squares Value \\
\hline Perceptions of Mobile Learning Media (X1) & - \\
\hline Self-Directed Learning (X2) & 0.958 \\
\hline Digital Literacy (X3) & 0.892 \\
\hline Critical Thinking Skills (Y) & 0.782 \\
\hline
\end{tabular}

Source: Primary data processed, 2020

Table 2 regarding the r-squares values indicates that the coefficient of determination on each variable was endogenous. In the variable of self-directed learning, the r-squares value was 0.958 , indicating that the variability of self-directed learning can be explained by the variable of perceptions of mobile learning media by $95.8 \%$. In comparison, the 
other $4.2 \%$ is explained by other factors outside the variables studied in this study. In the variable of digital literacy, the r-squares value was 0.892 , indicating that 21 st-century digital skills and entrepreneurship education can explain the variable of personal effectiveness competency in entrepreneurship by $89.2 \%$. In comparison, the other $10.8 \%$ is explained by other factors outside the variables examined in this study. In the variable of critical thinking skills, the r-squares value was 0.782 , indicating that the variable of critical thinking skills can be explained by self-directed learning and digital literacy by $78.2 \%$. In comparison, the other $21.8 \%$ is explained by other factors outside the variables researched in this study.

Path analysis results. The results of the analysis are derived and presented in the table as follows:

Table 3. Relationship between variables

\begin{tabular}{|l|c|l|}
\hline \multicolumn{1}{|c|}{ Variable } & Coefficient & \multicolumn{1}{c|}{ Relationship } \\
\hline Variable X1 $\rightarrow$ Variable X2 & 0.975 & Direct \\
\hline Variable X1 $\rightarrow$ Variable X3 & 0.948 & Direct \\
\hline Variable X1 $\rightarrow$ Variable $\mathrm{Y}$ & -1.275 & Direct \\
\hline Variable X2 $\rightarrow$ Variable $\mathrm{Y}$ & 0.844 & Direct \\
\hline Variable X3 $\rightarrow$ Variable Y & 1.317 & Direct \\
\hline Variable X1 $\rightarrow$ Variable X2 $\rightarrow$ Variable Y & 0.823 & Indirect \\
\hline Variable X1 $\rightarrow$ Variable X3 $\rightarrow$ Variable Y & 1.25 & Indirect \\
\hline
\end{tabular}

Source: Primary data processed, 2020.

Furthermore, the resulting research output is also presented through the path diagram as follows:

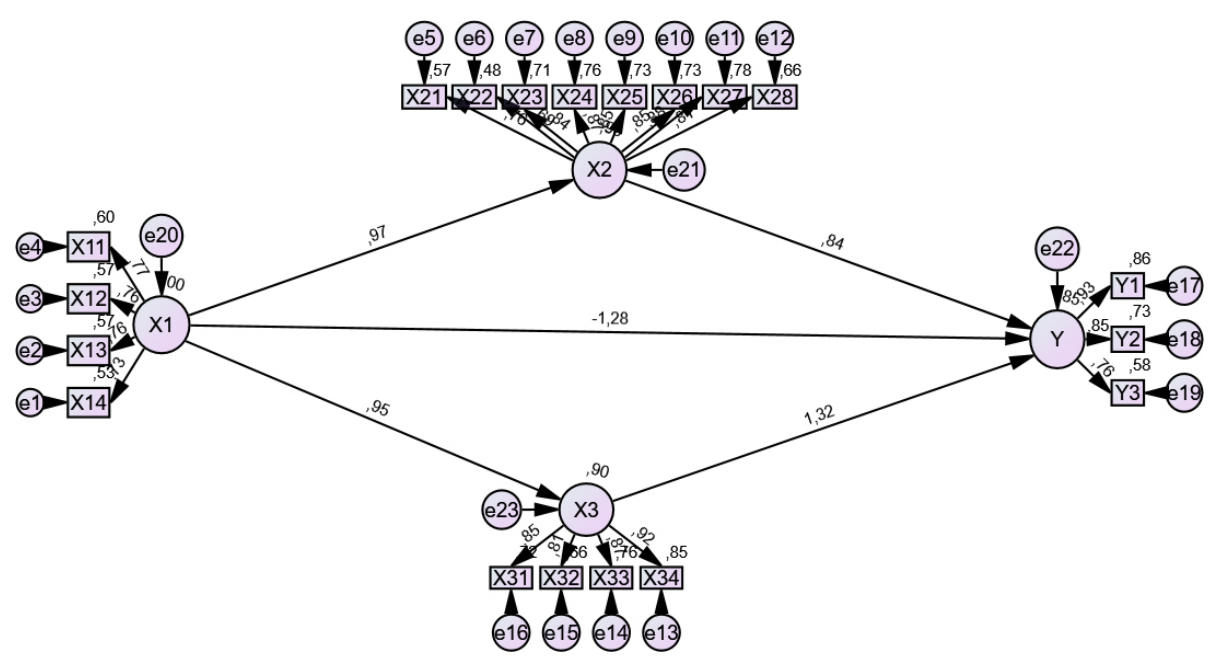

Fig. 1. Path diagram 
Table 3 and Figure 1 present the relationship between variables, obtaining a model consisting of 7 lines. The seven lines are composed of 5 lines with a direct relationship and two lines with an indirect relationship. Direct relationship means that no intermediate variables connect one variable to another. An indirect relationship means an intermediary variable (the mediating variable in this study) connects one variable.

The value of the direct and indirect relationships between variables can be found out through an equation based on the coefficient value. This study had four variables, including variable X1 (Perceptions of mobile-based learning media), variable X2 (Self-directed learning), variable X3 (digital literacy), and variable Y (critical thinking skills). The direct relationship between variable $\mathrm{X} 1$ and variable $\mathrm{X} 2$ was obtained from the cumulative coefficient of variable X1 and variable X2 (variable X1 $\rightarrow$ variable X2). The direct relationship between variable $\mathrm{X} 1$ and variable $\mathrm{X} 3$ was obtained from the cumulative coefficient of variable X1 and variable X3 (variable X1 $\rightarrow$ variable X3). The direct relationship between variable $\mathrm{X} 1$ and variable $\mathrm{Y}$ was obtained from the cumulative coefficient of variable X1 and variable $\mathrm{Y}$ (variable $\mathrm{X} 1 \rightarrow$ variable $\mathrm{Y}$ ). The direct relationship between variable $\mathrm{X} 2$ and variable $\mathrm{Y}$ was obtained from the cumulative coefficient of variable $\mathrm{X} 2$ and variable $\mathrm{Y}$ (variable $\mathrm{X} 2 \rightarrow$ variable $\mathrm{Y}$ ). The direct relationship between variable $\mathrm{X} 3$ and variable $\mathrm{Y}$ was obtained from the cumulative coefficient of variable X3 and variable Y (variable X3 $\rightarrow$ variable Y). Furthermore, the indirect relationship in this study was found in variable $\mathrm{X} 1$ to variable $\mathrm{Y}$ through variable X2 (the coefficient was obtained from the coefficient of variable X1 $\rightarrow$ variable X2 $\mathrm{x}$ the coefficient of variable $\mathrm{X} 2 \rightarrow \mathrm{Y}$ ) and variable $\mathrm{X} 1$ to variable $\mathrm{Y}$ through variable $\mathrm{X} 3$ (the coefficient was obtained from the coefficient of variable $\mathrm{X} 1 \rightarrow$ variable $\mathrm{X} 3 \mathrm{x}$ the coefficient of variable X3 $\rightarrow$ Y).

The goodness of fit test. The results of the goodness of fit test can be seen in the following table:

Table 4. The results of the goodness of fit model

\begin{tabular}{|l|l|c|}
\hline \multicolumn{1}{|c|}{ Measurement of the Goodness of Fit } & \multicolumn{1}{|c|}{ Threshold of the Goodness of Fit } & Results \\
\hline Chi-Square & The smaller, the better & 495.220 \\
\hline RMSEA & $0.05 \leq \mathrm{RMSEA} \leq 0.08$ & 0.112 \\
\hline TLI & $0.80 \leq \mathrm{TLI} \leq 1$ & 0.884 \\
\hline CFI & $0.80 \leq \mathrm{CFI} \leq 1$ & 0.900 \\
\hline NFI & $0.80 \leq \mathrm{NFI} \leq 1$ & 0.865 \\
\hline
\end{tabular}

Source: Primary data processed, 2020.

Table 4 presents the results of measuring the goodness of fit, showing the results of various measuring instruments. First, as seen from the chi-square, the result in this model was 495.220. These results indicate a high value and not following the threshold, given that the smaller the chi-square, the better. The chi-square number is susceptible to the number of samples, whereas this study had a large sample of 190 students. The use of the chi-square measuring instrument needs to be supported by other measuring instruments to obtain more representative results. The value of the second measuring 
instrument in this model of the Root Mean Square Error of Approximation (RMSEA) was 0.112 . The results show that the model conformity level was outside the requirements, indicating that this model has a moderate level of conformity when seen from the RMSEA.

It is essential to add measuring tools to meet the requirements so that the model is in a good category and can be used for further analysis. The following measuring tool was the Tucker-Lewis Index (TLI) and Normed Fit Index (NFI), measuring incremental fit by comparing the proposed model with the basic model. The TLI value was 0.884 , while the NFI value was 0.865 , indicating the model was in good fit criteria. The last measuring tool was the Comparative Fit Index (CFI), an incremental fit index and highly recommended because it is insensitive to the number of samples. The CFI value was 0.900 and was included in the good fit criteria. The conclusion is that the overall path analysis equation model was acceptable, and hypothesis testing can be continued.

Hypothesis testing. Hypothesis testing in this study used the regression weight analysis of the significance of the magnitude. This analysis was performed to determine the overall effect, direct effect, an indirect effect of the relationship between the variables researched. The basis for making decisions on this significance test include:

1) If the p-value $<$ alpha of 0.05 , then the hypothesis becomes null (0), and H0 is rejected, indicating that there is an effect between the two variables statistically (significant).

2) If the p-value $>$ alpha of 0.05, then the hypothesis becomes null (0), and H0 fails to be rejected, indicating that there are no effects between the two variables statistically (significant).

The following is a table of results of the analysis of the amount of regression on the path diagram:

Table 5. Weight regression results

\begin{tabular}{|l|c|l|l|l|}
\hline \multicolumn{1}{|c|}{ Path } & $\begin{array}{c}\text { Standardized } \\
\text { Beta }\end{array}$ & p-Value & \multicolumn{1}{|c|}{ Decision } & \multicolumn{1}{|c|}{$\begin{array}{c}\text { Types of } \\
\text { Relationships }\end{array}$} \\
\hline Variable X1 $\rightarrow$ Variable X2 & 0.975 & 0.000 & Significant & Positive \\
\hline Variable X1 $\rightarrow$ Variable X3 & 0.948 & 0.000 & Significant & Positive \\
\hline Variable X1 $\rightarrow$ Variable Y & -1.275 & 0.049 & Significant & Negative \\
\hline Variable X2 $\rightarrow$ Variable Y & 0.844 & 0.000 & Significant & Positive \\
\hline Variable X3 $\rightarrow$ Variable Y & 1.317 & 0.000 & Significant & Positive \\
\hline Variable X1 $\rightarrow$ Variable X2 $\rightarrow$ Variable Y & 0.823 & 0.000 & Significant & Positive \\
\hline Variable X1 $\rightarrow$ Variable X3 $\rightarrow$ Variable Y & 1.25 & 0.000 & Significant & Positive \\
\hline
\end{tabular}

As shown in Table 5 above, the Regression Weight results show significant values, indicating that all relationships of the variables have a significant effect. The following are the results of the hypothesis testing in detail: 
1. Hypothesis Testing 1

$\mathrm{H}_{0}$ : There is no significant positive effect on perceptions of mobile-based learning media on self-directed learning.

$\mathrm{H}_{1}$ : There is a significant positive effect on perceptions of mobile-based learning media on self-directed learning.

Based on the results of the hypothesis testing, the coefficient of the effect of perceptions on mobile-based learning media on self-directed learning was 0.975 . It indicates a positive coefficient which means that it had a positive relationship. Moreover, the $p$-value was $0.000<0.05$. It means that the relationship between these two variables was significant, so that $\mathrm{H}_{0}$ was rejected. It can be concluded that there was a significant positive effect on perceptions of mobile-based learning media on self-directed learning.

2. Hypothesis Testing 2

$\mathrm{H}_{0}$ : There is no significant positive effect on perceptions of mobile-based learning media on digital literacy.

$\mathrm{H}_{1}$ : There is a significant positive effect on perceptions of mobile-based learning media on digital literacy.

Based on the results of the hypothesis testing, the coefficient of the effect of perceptions on mobile-based learning media on digital literacy was 0.948 . These results indicate a positive coefficient which means that it had a positive relationship. Moreover, the $p$-value was $0.000<0.05$. It means that the relationship between these two variables was significant, so that $\mathrm{H}_{0}$ was rejected. In conclusion, there was a significant positive effect on perceptions of mobile-based learning media on digital literacy.

3. Hypothesis Testing 3

$\mathrm{H}_{0}$ : There is no significant positive effect of perceptions of mobile-based learning media on critical thinking skills.

$\mathrm{H}_{1}$ : There is a significant positive effect of perceptions of mobile-based learning media on critical thinking skills.

Based on the results of the hypothesis testing, the coefficient of the effect of perceptions on mobile-based learning media on critical thinking skills was -1.275 . These results indicate a positive coefficient which means that it had a positive relationship. Moreover, the $p$-value was $0.049<0.05$. It indicates that the relationship between these two variables was significant but had a negative relationship, so that $\mathrm{H}_{0}$ failed to be rejected. In conclusion, there was no significant positive effect on the variable of perceptions on mobile-based learning media on critical thinking skills.

4. Hypothesis Testing 4

$\mathrm{H}_{0}$ : There is no significant positive effect of self-directed learning on critical thinking skills.

$\mathrm{H}_{1}$ : There is a significant positive effect of self-directed learning on critical thinking skills.

Based on the results of the hypothesis testing, the coefficient of the effect of self-directed learning on critical thinking skills was 0.844 . These results indicate a positive coefficient which means that it had a positive relationship. Moreover, the $p$-value was $0.000<0.05$. This means that the relationship between these two variables was significant, so that $\mathrm{H}_{0}$ was rejected. The conclusion was that there was a significant positive indirect effect of self-directed learning on critical thinking skills. 
5. Hypothesis Testing 5

$\mathrm{H}_{0}$ : There is no significant positive effect of digital literacy on critical thinking skills.

$\mathrm{H}_{1}$ : There is a significant positive effect of digital literacy on critical thinking skills.

Based on the results of the hypothesis testing, the coefficient of the effect of digital literacy on critical thinking skills was 1.317 . These results indicate a positive coefficient which means that it had a positive relationship. Moreover, the $p$-value was $0.000<0.05$. It means that the relationship between these two variables was significant, so that $\mathrm{H}_{0}$ was rejected. In conclusion, there was a significant positive indirect effect of digital literacy on critical thinking skills.

6. Hypothesis Testing 6

$\mathrm{H}_{0}$ : There is no significant positive effect of perceptions on mobile-based learning media on critical thinking skills through self-directed learning skills.

$\mathrm{H}_{1}$ : There is a significant positive effect of perceptions of mobile-based learning media on critical thinking skills through self-directed learning skills.

Based on the results of the hypothesis testing, the coefficient of the effect of perceptions on mobile-based learning media on critical thinking skills through self-directed learning was 0.823 . These results indicate a positive coefficient which means that it had a positive relationship. Furthermore, the $p$-value was $0.000<0.05$. It means that the relationship between these two variables was significant, so that $\mathrm{H}_{0}$ was rejected. It can be concluded that there was a significant positive effect of perceptions of mobile-based learning media on critical thinking skills through self-directed learning abilities.

7. Hypothesis Testing 7

$\mathrm{H}_{0}$ : There is no significant positive effect of perceptions on mobile-based learning media on critical thinking skills through digital literacy.

$\mathrm{H}_{1}$ : There is a significant positive effect of perceptions of mobile-based learning media on critical thinking skills through digital literacy.

Based on the results of the hypothesis testing, the coefficient of the effect of perceptions on mobile-based learning media on critical thinking skills through digital literacy was 0.817 . These results indicate a positive coefficient which means that it had a positive relationship. Furthermore, the $p$-value was $0.000<0.05$. It means that the relationship between these two variables was significant, so that $\mathrm{H}_{0}$ was rejected. In conclusion, there was a significant positive effect on perceptions of mobile-based learning media on critical thinking skills through digital literacy.

\section{Discussion}

Perceptions of learning media measured through the student's point of view greatly influence students' habits. The measurement consisted of kinesthetic or ease of operation of the media, the experience of using media, learning motivation, and authenticity. First, the ease of operation will enable students to improve learning strategies and learning activities, which construct self-directed learning skills [15]. Second, the experience of using media becomes a stimulus to increase the level of students' awareness of 
the importance of learning and the establishment of student attitudes in learning which is a variable of self-directed learning [26]. Third, measuring learning motivation helps shape and improve interpersonal skills and motivation to learn independently. Finally, the authenticity of the media can uniquely construct knowledge based on the objectives of each media and can indoctrinate student learning methods according to the media applied. All media perceptions correspond to improvements in self-directed learning skills $[27,35,50]$.

On the other hand, perceptions of mobile-based learning media cannot be separated from the increase in digital literacy. First, ease of operation affects basic digital literacy skills $[6,28]$. Through easy operation, students can construct knowledge about digital technology used in learning. It can also improve skills in the ICT field [23]. In measuring experience and motivation in learning, these indicators can build the attitudes and perspectives of information users to show awareness in learning through the latest media [10].

After the behavior of self-directed learning is formed, critical thinking skills will be formed constructively. Independent learning is a learning strategy that is considered helpful in times of the pandemic as it happened today. The application of SDL can be carried out in various ways. One of them is the use of video game technology [58]. The application of SDL can also be carried out through digital technology precisely [2, 46]. Self-learning or self-direct learning has some objectives that must be achieved, such as increasing cognitive quality [12].

Furthermore, independent learning can also improve the quality of output of the students [27]. Based on these two objectives, it can be concluded that the main objective of SDL is the development of students, especially in the cognitive aspects. One of the skills that the development of students in the cognitive aspect needs to have is the ability to think critically. This is consistent with the findings from [25], which showed that SDL helps increase critical thinking skills using specific methods.

Critical thinking is not only formed through self-directed learning behavior but also adequate literacy skills. In this study, literacy has been narrowed down to digital literacy according to the media knowledge framework. The primary purpose of digital literacy is to create the skills to think according to the information obtained. In fact, in the formation of 21 st-century digital skills, the component needed to be integrated is critical thinking $[31,59]$. Critical thinking has been identified as an essential skill because, in an online environment, participation and resources are created with various intentions and competencies. Online content must be critically assessed in this age of disinformation and fake news. People need to understand its nature and source. The focus is on message quality concerning performance in the argument. It is essential for students to filter incoming online information and communications quickly and to extract valuable information. People must generate critical reflections on the points discussed online and provide argument support that leads to online discussions [31]. To improve critical thinking skills, people need to carry out efforts related to basic knowledge that is important to reformulate independently, argue from a particular perspective and have an opinion [61].

As revealed by the path analysis, there is an indirect relationship between perceptions of mobile-based learning media and critical thinking skills. Both of these variables were significant but negatively related. This is in line with several previous findings, 
which stated that perceptions of mobile-based learning media could not directly affect students' learning skills, such as thinking critically. Perceptions of the media must go through the variables of increasing learning behavior and master ICT to affect students' measurable abilities [22, 49, 63-64]. Therefore, the results in this study showed that the direct relationship between perceptions and students' skills are not proven, and the relationship between perceptions must go through an increase in self-directed learning and digital literacy to be able to positively and significantly affect students' critical thinking skills $[13,17,29]$.

\section{Challenges}

The challenge faced by the researchers in conducting this research is the presence of the COVID-19 pandemic so that the distribution of questionnaires is only done through online media. In addition, the researchers cannot directly monitor the condition of respondents when filling out the research instruments. This situation also forced the researchers to reschedule some respondents to fill out the instrument.

\section{Conclusions}

Based on the research results and discussion, the conclusions that can be drawn are: 1 ) the perceptions of mobile-based learning media cannot directly affect critical thinking skills, 2) critical thinking skills can be built from self-directed learning abilities, 3) critical thinking skills can be built from mastery of digital literacy, 4) self-directed learning skills can be built from students' perceptions of mobile-based learning media, 5) digital literacy skills can be built from students' perceptions of mobile-based learning media, 6) perceptions of mobile-based learning media can affect critical thinking skills through self-directed learning skills mediation, 7) perceptions of mobile-based learning media can affect critical thinking skills through digital literacy skills mediation. These results suggest a new theoretical framework regarding the use of mobile media to improve critical thinking skills. These results can serve as the latest contribution of critical thinking skills in the long term to enhance the quality of human resources due to the ongoing educational process.

\section{$8 \quad$ Limitations}

The research limitations are that the interpretation of the results can only describe the state of the relationship of the variables descriptively and is limited to the results of statistical processing on the questionnaire. For further research, the researchers hope that the results of this study can be utilized as a reference to prove the relationship between variables through classroom and experimental research. 


\section{$9 \quad$ References}

[1] Abu-Al-Aish, A., \& Love, S. (2013). Factors influencing students' acceptance of mlearning: An investigation in higher education. The International Review of Research in Open and Distributed Learning, 14(5). https://doi.org/10.19173/irrodl.v14i5.1631

[2] Adekitan, A. I., \& Noma-Osaghae, E. (2019). Data mining approach to predicting the performance of first year students in a university using the admission equirements. Educ. Inf. Technol. 24(2), 1527-1543. https://doi.org/10.1007/s10639-018-9839-7

[3] Amir, M. F., Fediyanto, N., Rudyanto, H. E., Nur Afifah, D. S., \& Tortop, H. S. (2020). Elementary students' perceptions of 3Dmetric: A cross-sectional study. Heliyon, 6(6). https:// doi.org/10.1016/i.heliyon.2020.e04052

[4] Aviles, M., \& Eastman, J. (2012). Utilizing technology effectively to improve Millennials' educational performance: An exploratory look at business students' perceptions. Journal of International Education in Business, 5, 96-113. https://doi.org/10.1108/18363261211281726

[5] Axelson, R., \& Flick, A. (2011). Defining student engagement. Change: The Magazine of Higher Learning, 43(1), 38-43. https://doi.org/10.1080/00091383.2011.533096

[6] Arts, I., Fischer, A., Duckett, D., \& van der Wal, R. (2021). Information technology and the optimization of experience - The role of mobile devices and social media in human-nature interactions. Geoforum, 122, 55-62. https://doi.org/10.1016/j.geoforum.2021.03.009

[7] Aznar-Díaz, I., Hinojo-Lucena, F. J., Cáceres-Reche, M. P., \& Romero-Rodríguez, J. M. (2020). Analysis of the determining factors of good teaching practices of mobile learning at the Spanish University. An explanatory model. Computers and Education, 159(September). https://doi.org/10.1016/j.compedu.2020.104007

[8] Baro, E. E., \& Aduba, E. D. (2019). An assessment of digital literacy skills and knowledge-based competencies among librarians working in university libraries in Africa. https:// doi.org/10.1108/DLP-04-2019-0013

[9] Bell, R., \& Loon, M. (2015). The impact of critical thinking disposition on learning using business simulations. International Journal of Management Education, 13(2), https://doi.org/ 10.1016/j.ijme.2015.01.002

[10] Bernacki, M. L., Greene, J. A., \& Crompton, H. (2020). Mobile technology, learning, and achievement: Advances in understanding and measuring the role of mobile technology in education. Contemporary Educational Psychology, 60, 101827. https://doi.org/10.1016/j. cedpsych.2019.101827

[11] Bezanilla, M. J., Fernández-Nogueira, D., Poblete, M., \& Galindo-Domínguez, H. (2019). Methodologies for teaching-learning critical thinking in higher education: The teacher's view. Thinking Skills and Creativity, 33(February), 100584. https://doi.org/10.1016/j. tsc.2019.100584

[12] Cadorin, L., Bortoluzzi, G., \& Palese, A. (2013). The self-rating scale of self-directed learning (SRSSDL): A factor analysis of the Italian version. Nurse Education Today, 33(12), 1511-1516. https://doi.org/10.1016/j.nedt.2013.04.010

[13] Chan, C. (2019). Using digital storytelling to facilitate critical thinking disposition in youth civic engagement: A randomized control trial. Children and Youth Services Review, 107(October), 104522. https://doi.org/10.1016/j.childyouth.2019.104522

[14] Chaplin. (2011). Kamus Lengkap Psikologi. Jakarta: PT. RajaGrafindo Persada.

[15] Chen, C. P. (2018). Understanding mobile English-learning gaming adopters in the self-learning market: The Uses and Gratification Expectancy Model. Computers and Education, 126(July 2018), 217-230. https://doi.org/10.1016/j.compedu.2018.07.015 
[16] de Bruin, A. B., \& van Merriënboer, J. J. (2017). Bridging cognitive load and self-regulated learning research: A complementary approach to contemporary issues in educational research. Learning and Instruction, 51, 1-9. https://doi.org/10.1016/j.learninstruc.2017.06.001

[17] Dekker, T. J. (2020). Teaching critical thinking through engagement with multiplicity. Thinking Skills and Creativity, 37(July), 100701. https://doi.org/10.1016/j.tsc.2020.100701

[18] Facione, P. A. (2011). Critical Thinking : What It Is and Why It Counts. Insight Assessment, (ISBN 13: 978-1-891557-07-1.), 1-28.

[19] Forawi, S. A. (2016). Standard-based science education and critical thinking. Thinking Skills and Creativity, 20, 52-62. https://doi.org/10.1016/j.tsc.2016.02.005

[20] Forawi, S. A., \& Mitchell, R. M. (2012). Pre-Service Teachers 'Perceptions of Critical Thinking Attributes of the Ohio and New York States' Math and. 1(5), 379-388.

[21] Hatlevik, O. E., Ottestad, G., \& Throndsen, I. (2015). Predictors of digital competence in 7th grade: A multilevel analysis. Journal of Computer Assisted Learning, 31(3), 220-231. https://doi.org/10.1111/jcal.12065

[22] Hundial, H. (2020). The Safe Care FrameworkTM: A practical tool for critical thinking. Nurse Education in Practice, 48, 102852. https://doi.org/10.1016/j.nepr.2020.102852

[23] Irhandayaningsih, A. (2020). Pengukuran Literasi Digital Pada Peserta Pembelajaran Daring di Masa Pandemi COVID-19. ANUVA, 4(2), 231-240. https://doi.org/10.21009/PIP.342.9

[24] June, S., Yaacob, A., \& Kheng, Y. K. (2014). Assessing the use of YouTube videos and interactive activities as a critical thinking stimulator for tertiary students: An action research. International Education Studies, 7(8), 56-67. Retrieved from https://eric.ed.gov/?id=EJ1070444. https://doi.org/10.5539/ies.v7n8p56

[25] Kang, S. J., Hong, C. M., \& Lee, H. (2020). The Impact of Virtual Simulation on Critical Thinking and Self-Directed Learning Ability of Nursing Students. Clinical Simulation in Nursing, 1-7. https://doi.org/10.1016/j.ecns.2020.05.008

[26] Karimi, S. (2016). Do learners' characteristics matter? An exploration of mobile-learning adoption in self-directed learning. Computers in Human Behavior, 63, 769-776. https://doi. org/10.1016/j.chb.2016.06.014

[27] Kastenmeier, A. S., Redlich, P. N., Fihn, C., Treat, R., Chou, R., Homel, A., \& Lewis, B. D. (2018). Individual learning plans foster self-directed learning skills and contribute to improved educational outcomes in the surgery clerkship. American Journal of Surgery, 216(1), 160166. https://doi.org/10.1016/j.amjsurg.2018.01.023

[28] Klimova, B. (2020). Benefits of the use of mobile applications for learning a foreign language by elderly population. Procedia Computer Science, 176, 2184-2191. https://doi. org/10.1016/j.procs.2020.09.255

[29] Kong, S. C. (2014). Developing information literacy and critical thinking skills through domain knowledge learning in digital classrooms: An experience of practicing flipped classroom strategy. Computers and Education, 78, 160-173. https://doi.org/10.1016/j. compedu.2014.05.009

[30] Kulakow, S., \& Raufelder, D. (2020). Enjoyment benefits adolescents' self-determined motivation in student-centered learning. International Journal of Educational Research, 103(April), 101635. https://doi.org/10.1016/j.ijer.2020.101635

[31] Laar, E. Van, Deursen, A. J. A. M. Van, Dijk, J. A. G. M. Van, \& Haan, J. De. (2020). Determinants of 21st-Century Skills and 21st-Century Digital Skills for Workers: A Systematic Literature Review. https://doi.org/10.1177/2158244019900176

[32] Lalitha, T. B., \& Sreeja, P. S. (2020). Personalised Self-Directed Learning Recommendation System. Procedia Computer Science, 171(2019), 583-592. https://doi.org/10.1016/j. procs.2020.04.063 
[33] Lee, H., Parsons, D., Kwon, G., Kim, J., Petrova, K., Jeong, E., \& Ryu, H. (2016). Cooperation begins: Encouraging critical thinking skills through cooperative reciprocity using a mobile learning game. Computers and Education, 97, 97-115. https://doi.org/ 10.1016/j.compedu.2016.03.006

[34] Liu, Q., Chen, H., \& Crabbe, M. J. C. (2021). Interactive Study of Multimedia and Virtual Technology in Art Education. International Journal of Emerging Technologies in Learning (iJET), 16(1), 80. https://doi.org/10.3991/ijet.v16i01.18227

[35] Louws, M. L., Meirink, J. A., van Veen, K., \& van Driel, J. H. (2017). Teachers' self-directed learning and teaching experience: What, how, and why teachers want to learn. Teaching and Teacher Education, 66, 171-183. https://doi.org/10.1016/j.tate.2017.04.004

[36] Mulà, I., Tilbury, D., Ryan, A., Mader, M., Dlouhá, J., Mader, C., ... Alba, D. (2017). Catalysing change in higher education for sustainable development. Int. J. Sustain. High. Educ., 18(5), 798-820. https://doi.org/10.1108/IJSHE-03-2017-0043

[37] Näykki, P., Isohätälä, J., Järvelä, S., Pöysä-Tarhonen, J., \& Häkkinen, P. (2017). Facilitating sociocognitive and socio-emotional monitoring in collaborative learning with a regulation macro script - an exploratory study. International Journal of Computer- Supported Collaborative Learning, 12(3), 251-279. https://doi.org/10.1007/s11412-017-9259-5

[38] Noblitt, L., Vance, D. E., \& Smith, M. L. D. (2010). A comparison of case study and traditional teaching methods for improvement of oral communication and criticalthinking skills. Journal of College Science Teaching, 39(5), 26-32.

[39] OECD. (2018). What 15-year-old students in Indonesia know and can do. Programme for International Student Assessment (PISA) Result from PISA 2018, 1-10. Retrieved from http://www.oecd.org/pisa/ Data

[40] Pan, Q. (2019). An interactive teaching mode based on educational games - Case study of acupuncture course. International Journal of Emerging Technologies in Learning, 14(17), 167-181. https://doi.org/10.3991/ijet.v14i17.11205

[41] Papadakis, S. (2020). Apps to Promote Computational Thinking Concepts and Coding Skills in Children of Preschool and Pre-Primary School Age. In Mobile Learning Applications in Early Childhood Education (pp. 101-121). IGI Global. https://doi. org/10.4018/978-1-7998-1486-3.

[42] Papadakis, S. (2020). Tools for evaluating educational apps for young children: a systematic review of the literature. Interactive Technology and Smart Education, Vol. ahead-of-print No. ahead-of-print. https://doi.org/10.1108/ITSE-08-2020-0127

[43] Papadakis, S., \& Kalogiannakis, M. (2020). A research synthesis of the real value of self-proclaimed mobile educational applications for young children. Mobile learning applications in early childhood education, 1-19. https://doi.org/10.4018/978-1-7998-1486-3.ch001

[44] Papadakis, S., Vaiopoulou, J., Kalogiannakis, M., Stamovlasis, D. (2020). Developing and Exploring an Evaluation Tool for Educational Apps (ETEA.) Targeting Kindergarten Children. Sustainability, 12, 4201. https://doi.org/10.3390/su12104201

[45] Prayaga, P., Rennie, E., Pechenkina, E., \& Hunter, A. (2017). Digital Literacy and Other Factors Influencing the Success of Online Courses in Remote Indigenous Communities. https://doi.org/10.1007/978-981-10-4062-7

[46] Quinn, S., Hogan, M., Dwyer, C., Finn, P., \& Fogarty, E. (2020). Development and Validation of the Student-Educator Negotiated Critical Thinking Dispositions Scale (SENCTDS). Thinking Skills and Creativity, 38(May), 100710. https://doi.org/10.1016/j.tsc.2020.100710

[47] Rashid, T., \& Asghar, H. M. (2016). Technology use, self-directed learning, student engagement and academic performance: Examining the interrelations. Computers in Human Behavior, 63, 604-612. https://doi.org/10.1016/i.chb.2016.05.084 
[48] Rusli, R., Rahman, A., \& Abdullah, H. (2020). Student perception data on online learning using heutagogy approach in the Faculty of Mathematics and Natural Sciences of Universitas Negeri Makassar, Indonesia. Data in Brief, 29, 105152. https://doi.org/10.1016/j. dib.2020.105152

[49] Sarigoz, O. (2012). Assessment of the High School Students' Critical Thinking Skills. Procedia - Social and Behavioral Sciences, 46, 5315-5319. https://doi.org/10.1016/j. $\underline{\text { sbspro.2012.06.430 }}$

[50] Sawyer, K. (2012). Extending sociocultural theory to group creativity. Vocations and Learning, 5(1), 59-75.

[51] Sawyer, K. (2014). The future of Learning: Grounding educational innovation in the Learning sciences. In R. K. Sawyer (Ed.). The Cambridge handbook of the learning sciences (pp. 726-746). New York, NY: Cambridge University Press.

[52] Seidman, I. (2013). Interviewing as qualitative research: A. Guide for researchers in education and the social sciences (4th ed.). New York: Teachers College Press.

[53] Sophonhiranrak, S. (2021). Features, barriers, and influencing factors of mobile learning in higher education: A systematic review. Heliyon, 7(4), e06696. https://doi.org/10.1016/j. heliyon.2021.e06696

[54] Suratno, Narmaditya, B. S., \& Wibowo, A. (2021). Family economic education, peer groups and students' entrepreneurial intention: the mediating role of economic literacy. Heliyon, 7(4), e06692. https://doi.org/10.1016/j.heliyon.2021.e06692

[55] Toh, W., \& Kirschner, D. (2020). Self-directed learning in video games, affordances and pedagogical implications for teaching and learning. Computers and Education, 154(May), 103912. https://doi.org/10.1016/j.compedu.2020.103912

[56] Untari, R. S., Kamdi, W., Dardiri, A., Hadi, S., \& Nurhadi, D. (2020). The development and application of interactive multimedia in project-based learning to enhance students' achievement for 2D animation making. International Journal of Emerging Technologies in Learning, 15(16), 17-30. https://doi.org/10.3991/ijet.v15i16.16521

[57] Uus, Õ., Seitlinger, P. C., \& Ley, T. T. (2020). Cognitive capacity in self-directed learning: Evidence of middle school students' executive attention to resist distraction. Acta Psychologica, 209(May), 103089. https://doi.org/10.1016/j.actpsy.2020.103089

[58] van de Oudeweetering, K., \& Voogt, J. (2018). Teachers' conceptualization and enactment of twenty-first century competences: exploring dimensions for new curricula. Curriculum Journal, 29(1), 116-133. https://doi.org/10.1080/09585176.2017.1369136

[59] van Laar, E., van Deursen, A. J. A. M., van Dijk, J. A. G. M., \& de Haan, J. (2017). The relation between 21st-century skills and digital skills: A systematic literature review. Computers in Human Behavior, 72, 577-588. https://doi.org/10.1016/j.chb.2017.03.010

[60] van Laar, E., van Deursen, A. J. A. M., van Dijk, J. A. G. M., \& de Haan, J. (2018). 21st-century digital skills instrument aimed at working professionals: Conceptual development and empirical validation. Telematics and Informatics, 35(8), 2184-2200. https://doi. org/10.1016/j.tele.2018.08.006

[61] Walsh, C., Chappell, K., \& Craft, A. (2017). A co-creativity theoretical framework to foster and evaluate the presence of wise humanising creativity in virtual learning environments (VLEs). Thinking Skills and Creativity, 24, 228-241. https://doi.org/10.1016/j. $\underline{\text { tsc.2017.01.001 }}$

[62] Wiana, W., Syaom Barliana, M., \& Riyanto, A. A. (2018). The effectiveness of using interactive multimedia based on motion graphic in concept mastering enhancement and fashion designing skill in digital format. International Journal of Emerging Technologies in Learning, 13(2), 4-20. https://doi.org/10.3991/ijet.v13i02.7830 
[63] ŽivkoviL, S. (2016). A Model of Critical Thinking as an Important Attribute for Success in the 21st Century. Procedia - Social and Behavioral Sciences, 232(April), 102-108. https:// doi.org/10.1016/j.sbspro.2016.10.034

[64] Papadakis, S. (2021). The Impact of Coding Apps to Support Young Children in Computational Thinking and Computational Fluency. A Literature Review. Front. Educ. 6,657895. doi: https://doi.org/10.3389/feduc.2021.657895

[65] Kalogiannakis, M., Papadakis, S., \& Zourmpakis, A. I. (2021). Gamification in Science Education. A Systematic Review of the Literature. Education Sciences, 11(1), 22. https:// doi.org/10.3390/educsci11010022

\section{Authors}

Dra. Patni Ninghardjanti, M.Pd was born in Surakarta on April 06, 1963. The last edition of Education Research and Evaluation Education UNY, a journal that has been published in aspapi journal, is also active in book writing: Computer administration practice, Office Administration Computer. He is currently a lecturer in the FKIP UNS office administration education study program and is active in ASPAPI.

Chairul Huda Atma Dirgatama, S.Pd, M.Pd was born in Kebumen on December 19, 1992. The last education of S2 Economic Education Concentration of Office Administration. Journal work was published in Journal of Edulearn, International Journal of Multiscience, Jurnal Vokasi Indonesia, Journal of Physics, and Jurnal JIKAP. In addition, active in the writing of books: digital archives, public relations, multimedia based mobile learning, automation record and staffing administration. He is currently a lecturer in the Vocational School Administration Management Study Program UNS and is active in ASPAPI.

Article submitted 2021-05-06. Resubmitted 2021-06-30. Final acceptance 2021-06-30. Final version published as submitted by the authors. 